\title{
Generation of Hydroxyl Radical by Enzymes, Chemicals, and Human Phagocytes In Vitro
}

\author{
DETECTION WITH THE ANTI-INFLAMMATORY
}

AGENT, DIMETHYL SULFOXIDE

\author{
John E. REPINE, John W. EATON, M. W. ANDERS, John R. HoIdAL, and Richard B. FoX, \\ Departments of Medicine and Pediatrics, Webb-Waring Lung Institute, University \\ of Colorado Health Sciences Center, Denver, Colorado 80262; \\ Departments of Laboratory Medicine and Pathology and Pharmacology, \\ University of Minnesota Health Sciences Center, Minneapolis, Minnesota 55455
}

A B S T RACT Methane $\left(\mathrm{CH}_{4}\right)$ production from the anti-inflammatory agent, dimethyl sulfoxide (DMSO), was used to measure $\cdot \mathrm{OH}$ from chemical reactions or human phagocytes. Reactions producing $\cdot \mathrm{OH}$ (xanthine/xanthine oxidase or $\mathrm{Fe}^{++} / \mathrm{EDTA} / \mathrm{H}_{2} \mathrm{O}_{2}$ ) generated $\mathrm{CH}_{4}$ from DMSO, whereas reactions yielding primarily $\mathrm{O}_{2}^{-}$or $\mathrm{H}_{2} \mathrm{O}_{2}$ failed to produce $\mathrm{CH}_{4}$. Neutrophils (PMN), monocytes, and alveolar macrophages also produced $\mathrm{CH}_{4}$ from DMSO. Mass spectroscopy using $\mathrm{d}_{6}$-DMSO showed formation of $\mathrm{d}_{3}-\mathrm{CH}_{4}$ indicating that $\mathrm{CH}_{4}$ was derived from DMSO. Methane generation by normal but not chronic granulomatous disease or heat-killed phagocytes increased after stimulation with opsonized zymosan particles or the chemical, phorbol myristate acetate. Methane production from DMSO increased as the number of stimulated PMN was increased and the kinetics of $\mathrm{CH}_{4}$ production approximated other metabolic activities of stimulated PMN. Methane production from stimulated phagocytes and DMSO was markedly decreased by purportedly potent -OH scavengers (thiourea or tryptophane) and diminished to lesser degrees by weaker $\cdot \mathrm{OH}$ scavengers (mannitol, ethanol, or sodium benzoate). Superoxide dismutase or catalase also decreased $\mathrm{CH}_{4}$ production but urea, albumin, inactivated superoxide dismutase, or boiled catalase had no appreciable effect. The results suggest that the production of $\mathrm{CH}_{4}$ from DMSO

Dr. Repine is an Established Investigator of the American Heart Association. Address reprint requests to Dr. Repine at Webb-Waring Lung Institute. Dr. Eaton is a recipient of a National Institutes of Health Career Development award. Dr. Hoidal is the recipient of a Young Pulmonary Investigator award. Dr. Fox is a Fellow of the American Lung Association.

Received for publication 5 April 1979 and in revised form 15 August 1979. may reflect release of $\cdot \mathrm{OH}$ from both chemical systems and phagocytic cells. Interaction of the nontoxic, highly permeable DMSO with $\cdot \mathrm{OH}$ may explain the antiinflammatory actions of DMSO and provide a useful measurement of $\cdot \mathrm{OH}$ in vitro and in vivo.

\section{INTRODUCTION}

Stimulated phagocytes use oxygen $\left(\mathrm{O}_{2}\right)$ and produce highly reactive $\mathrm{O}_{2}$ metabolites $(1,2)$. Several $\mathrm{O}_{2}$ metabolites, including superoxide anion $\left(\mathrm{O}_{\overline{2}}^{\overline{2}}\right)$, hydrogen peroxide $\left(\mathrm{H}_{2} \mathrm{O}_{2}\right)$, hydroxyl radical $(\cdot \mathrm{OH})$, and perhaps, singlet oxygen $\left({ }^{1} \mathrm{O}_{2}\right)$, are made by phagocytes and appear to be involved in their bactericidal and/or cytotoxic capabilities $(1,3)$. Because $\mathrm{O}_{2}^{-}$and $\mathrm{H}_{2} \mathrm{O}_{2}$ may form $\cdot \mathrm{OH}$ in the presence of trace metals $(4,5)$, recent investigations have focused on determining the importance of $\mathrm{OH}$ by measuring the production of ethylene $\left(\mathrm{C}_{2} \mathrm{H}_{4}\right)$ by stimulated phagocytes in the presence of thioethers, such as $\beta$-methyl-propionaldehyde (methional) or 2-keto-4-thiomethyl-butyric acid $(\mathrm{KMB})^{1}(6-10)$ :

$$
\begin{gathered}
\cdot \mathrm{OH}+\underset{(\text { methional })}{\mathrm{HCOCH}_{2} \mathrm{CH}_{2} \mathrm{SCH}_{3} \rightarrow} \\
\qquad \mathrm{C}_{2} \mathrm{H}_{4}+\frac{1 / 2\left(\mathrm{CH}_{3} \mathrm{~S}\right)_{2}+\mathrm{HCOOH}}{(\text { ethylene })} \\
. \mathrm{OH}+\underset{(\mathrm{KMB})}{\mathrm{CH}_{3} \mathrm{SCH}_{2} \mathrm{CH}_{2} \mathrm{COCOOH} \rightarrow} \\
\mathrm{C}_{2} \mathrm{H}_{4}+1 / 2\left(\mathrm{CH}_{3} \mathrm{~S}\right)_{2}+\mathrm{HCOOH}+\mathrm{CO}_{2} \\
(\text { ethylene })
\end{gathered}
$$

${ }^{1}$ Abbreviations used in this paper: AM, alveolar monocytes; CGD, chronic granulomatosus disease; DMSO, dimethyl 
Indeed, stimulated neutrophils (PMN), monocytes (MN) or alveolar marcophages (AM) do produce $\mathrm{C}_{2} \mathrm{H}_{4}$ from methional or KMB (6-10). However, the strict dependence of $\mathrm{C}_{2} \mathrm{H}_{4}$ production upon $\cdot \mathrm{OH}$ is in doubt $(8,10-14)$. Methional spontaneously forms $\mathrm{C}_{2} \mathrm{H}_{4}$, especially during prolonged incubations with tissues (8), and can also react with $\mathrm{H}_{2} \mathrm{O}_{2}$ to form $\mathrm{C}_{2} \mathrm{H}_{4}(10)$. The specificity of $\mathrm{KMB}$ as a detector of $\cdot \mathrm{OH}$ is also in question because $\mathrm{C}_{2} \mathrm{H}_{4}$ production from KMB may reflect, at least in part, reactions with ${ }^{1} \mathrm{O}_{2}$ or hypochlorous acid (10).

In the course of comparing the generation of $\mathrm{C}_{2} \mathrm{H}_{4}$ from $\mathrm{KMB}$ in the presence of opsonized zymosan particles or phorbol myristate acetate (PMA) stimulated PMN, we observed that the latter samples also synthesized methane $\left(\mathrm{CH}_{4}\right)$. Additional experiments indicated that the $\mathrm{CH}_{4}$ arose from the dimethyl sulfoxide (DMSO) used as a solvent for PMA (15). Because others have used DMSO as a scavenger of - $\mathrm{OH}$ (16-25), and because $\mathrm{CH}_{4}$ might be produced as a result of this reaction (20-22), the present investigations were designed to examine the validity of using DMSO as a detector of $\cdot \mathrm{OH}$.

\section{METHODS}

Reagents. Xanthine oxidase (grade I, buttermilk), KMB, catalase (bovine liver, crystallized twice), superoxide dismutase (SOD, type 1, 3,000 U/mg protein), thiourea (grade I), urea, scopoletin (7-OH-6-methoxycoumarin), zymosan A, DMSO (Grade I), sodium azide, L-tryptophane, mannitol, xanthine, horse-heart ferricytochrome $c$, and DL-histidine were obtained from Sigma Chemical Co., St. Louis, Mo. Ferrous sulfate (Baker Adamson, Morriston, N. J.), EDTA (Sigma Chemical Co., St. Louis, Mo.), $\mathrm{H}_{2} \mathrm{O}_{2}$ (Mallinckrodt, Inc., St. Louis, Mo.), sodium benzoate (J. T. Baker Chemical Co., Phillipsburg, N. J.), PMA (12-O-tetradeconyl-phorbol-13acetate, Consolidated Midland Corp., Brewster, N. Y.), and human serum albumin (25\%, Cutter Laboratories, Inc., Berkeley, Calif.) were used as purchased.

Recovery and preparation of human PMN, MN, and AM. This investigation was approved by the Human Volunteers Committee of the University of Minnesota. Blood was collected from healthy volunteers not taking medications and from two patients with proven X-linked chronic granulomatosus disease (CGD) in good health at the time of venipuncture. Blood $(30 \mathrm{ml})$ was drawn into a plastic syringe that contained $1,000 \mathrm{U}$ of sodium heparin and allowed to sediment with $5 \mathrm{ml}$ of 6\% dextran in saline (Dextran 75, Travenol Laboratories, Inc., Morton Grove, Ill.) for $90 \mathrm{~min}$ (26). PMN or MN were separated by differential centrifugation on Ficoll (Pharmacia Fine Chemicals, Inc., Piscataway, N. J.)-Hypaque (Winthrop Laboratories, New York), washed once and resuspended in Hanks' balanced salt solution (HBSS) without $\mathrm{Ca}^{++}$and $\mathrm{Mg}^{++}$ (26). Contaminating erythrocytes were lysed by adding $6 \mathrm{ml}$ of ice-cold sterile distilled water and mixing gently for $35 \mathrm{~s}$. Tonicity was rapidly restored with $2 \mathrm{ml}$ of hypertonic

sulfoxide; HBSS, Hanks' balanced salt solution; KMB, 2-keto4-thiomethylbutyric acid; m/e, mass/charge; MN, monocytes; PMA, phorbol myristate acetate; PMN, neutrophils; SOD, superoxide dismutase.
(4× $\mathrm{Ca}^{++}$and $\mathrm{Mg}^{++}$free HBSS. The mixture was then centrifuged at $170 \mathrm{~g}$ for $10 \mathrm{~min}$. Cells in the pellet were then washed once more, resuspended in HBSS with $\mathrm{Ca}^{++}$and $\mathrm{Mg}^{++}$, counted, and used immediately. PMN preparations contained $>98 \%$ PMN with only a few lymphocytes and rare erythrocytes, platelets or MN. Suspensions of MN were similarly prepared. The percentages of $M N$ were determined by differential counting of 600 cells on Wright's stained smears and cytochemically confirmed by esterase stain. MN preparations contained $\sim 30 \% \mathrm{MN},<1 \% \mathrm{PMN}$, and the remainder lymphocytes. AM were obtained by bronchoscopic sterile saline lavage of the unaffected subsegments of the lungs of patients undergoing evaluations for localized pulmonary disease or from healthy volunteers (9). AM were recovered from lavage fluids, washed once, and counted. The final preparations contained $>90 \% \mathrm{AM}$ and $<2 \%$ PMN. More than $85 \%$ of the AM excluded trypan blue. Concentrations of lymphocytes or platelets that were comparable to those remaining in phagocyte preparations did not produce significant amounts of $\mathrm{CH}_{4}$ from DMSO.

Preparation of pooled human serum, opsonized zymosan, or PMA. Pooled human serum was prepared from clotted blood from five or more control subjects, pooled, and frozen in aliquots at $-70^{\circ} \mathrm{C}$ for less than 2 wk before use (27). Zymosan A, $50 \mathrm{mg}$, was washed with HBSS, opsonized with $1 \mathrm{ml}$ pooled human serum at $37^{\circ} \mathrm{C}$ for $30 \mathrm{~min}$, centrifuged at $700 \mathrm{~g}$ for $5 \mathrm{~min}$, and resuspended in HBSS. PMA was dissolved in DMSO and stored in the dark at $4^{\circ} \mathrm{C}(15)$.

Measurement of $\mathrm{CH}_{4}$ or $\mathrm{C}_{2} \mathrm{H}_{4}$ production. For studies of phagocytic cell function, siliconized $(3 \mathrm{ml})$ glass tubes were prepared by sequentially adding DMSO or KMB, PMN, MN, or AM in HBSS, and then HBSS, opsonized zymosan or PMA in HBSS (final volume $1 \mathrm{ml}$ ). These concentrations of zymosan or PMA produced maximal rates of $\mathrm{O}_{2}$ uptake, $\mathrm{O}_{i}^{-}$ formation, and chemiluminescence by PMN. The tubes were then rapidly sealed with rubber stoppers and incubated at $37^{\circ} \mathrm{C}$ in a shaking water bath.

For studies with chemical reactions, tubes were prepared by successive additions of DMSO, KMB, phosphate-buffered HBSS, pH 7.8, EDTA, and/or xanthine. The tubes were then capped and either $\mathrm{H}_{2} \mathrm{O}_{2}$ or xanthine oxidase was injected through the rubber stopper. Subsequently, the reactions were mixed, incubated at $30^{\circ} \mathrm{C}$ in a water bath for $20 \mathrm{~min}$, and placed on ice.

Samples of the headspace gas in each tube were introduced into a gas chromatograph (series 1400, flame ionization detector, Varian Associates, Palo Alto, Calif.) via a $0.25-\mathrm{ml}$ gas sampling loop $(10,28)$. A $1 / 8$ in. $\times 6 \mathrm{ft}$ stainless steel column packed with Carbosieve B 60/80 mesh (Supelco, Inc., Bellefonte, $\mathrm{Pa}$.) was used. The injector, detector, and column temperatures were $200^{\circ}, 200^{\circ}$, and $120^{\circ} \mathrm{C}$, respectively. The retention time for $\mathrm{CH}_{4}$ was $0.5 \mathrm{~min}$ and for $\mathrm{C}_{2} \mathrm{H}_{4}$ was $2.5 \mathrm{~min}$. Analyses of $\mathrm{CH}_{4}$ or $\mathrm{C}_{2} \mathrm{H}_{4}$ standards ( $100 \mathrm{ppm}$, Scott Specialty Gases, division of Scott Environmental Technology, Inc., Plumsteadville, $\mathbf{P a}$.) were included with each experiment. The $\mathrm{CH}_{4}$ or $\mathrm{C}_{2} \mathrm{H}_{4}$ contents of each test sample were determined by comparing the peak heights of experimental samples with those of standards. The $\mathrm{CH}_{4}$ present in lab air was subtracted from each reading. The concentration of the gas in the headspace $(2 \mathrm{ml})$ was initially measured in parts per million and was expressed as picomoles of $\mathrm{CH}_{4}$ or $\mathrm{C}_{2} \mathrm{H}_{4}$.

Measurement of $d_{3} \mathrm{CH}_{4}$ by gas chromatography/mass spectroscopy. $\mathrm{d}_{3}-\mathrm{CH}_{4}$ produced from $\mathrm{d}_{6}-\mathrm{DMSO}(99.5 \%$ atom $\%$ Merck Chemical Div., Merck \& Co., Inc., Rahway, N. J.) was identified using a Finnigan model 1015 gas chromatography/ mass spectroscope (Finnigan Corp., Sunnyvale, Calif.) equipped with a $5 \mathrm{ft} \times 2 \mathrm{~mm}$ i.d. glass column packed with Carbosieve-B 60/80 mesh (Supelco, Inc.) maintained at $160^{\circ} \mathrm{C}$ 


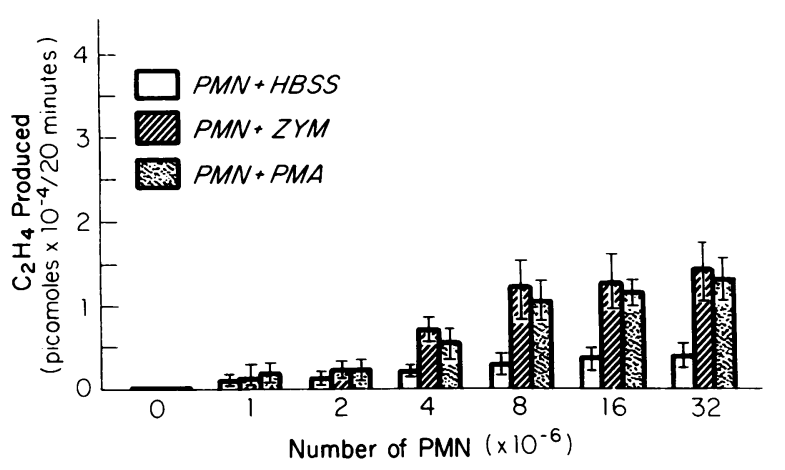

FIgURE 1 Generation of $\mathrm{C}_{2} \mathrm{H}_{4}$ by human $\mathrm{PMN}$ as a function of the number of $\mathrm{PMN}$. $\mathrm{C}_{2} \mathrm{H}_{4}$ production progressively increased as the number of PMN was increased from 1 to $8 \times 10^{6}$, but did not increase as the number of PMN was increased from 8 to 32 $\times 10^{6}$.

$(29,30)$. The mass spectrometer operating parameters were adjusted to yield maximal signal and resolution. Samples were introduced via a gas sampling value equiped with a $0.7 \mathrm{ml}$ sampling loop. Spectra were recorded over the range mass/charge (m/e) 15-19 before and during elution of the $\mathrm{CH}_{4}$ peak. The relative abundance of ions at m/e 16-19 were calculated using $\mathrm{m} / \mathrm{e} 19\left(\mathrm{~d}_{3}-\mathrm{CH}_{4}\right)$ as the base peak and the background values subtracted from those recorded during elution of the $\mathrm{CH}_{4}$ peak to yield the mass spectrum of $\mathrm{d}_{3}-\mathrm{CH}_{4}$. Ions at $\mathrm{m} / \mathrm{e} 18$ were not included because of the large background contribution of water.

Measurement of $\mathrm{O}_{2}^{-}$. Production of $\mathrm{O}_{2}^{-}$was determiend by measuring $\mathrm{O}_{\overline{2}}^{\overline{2}}$-dependent reduction of horse heart ferricytochrome $c$ spectrophotometrically (31).

Measurement of $\mathrm{H}_{2} \mathrm{O}_{2} . \quad \mathrm{H}_{2} \mathrm{O}_{2}$ was measured using the standard fluorometric scopoletin assay (32).

Measurement of $\mathrm{O}_{2}$ consumption. $\mathrm{O}_{2}$ uptake by $\mathrm{PMN}$ was performed using a biologic $\mathrm{O}_{2}$ probe attached to an oxygen analyzer and Beckman recorder (15).

Measurement of $\left[1-1^{14} \mathrm{C}\right]$ glucose oxidation. $\left[1-{ }^{14} \mathrm{C}\right] \mathrm{Glucose}$ oxidation was determined by measuring the amount of

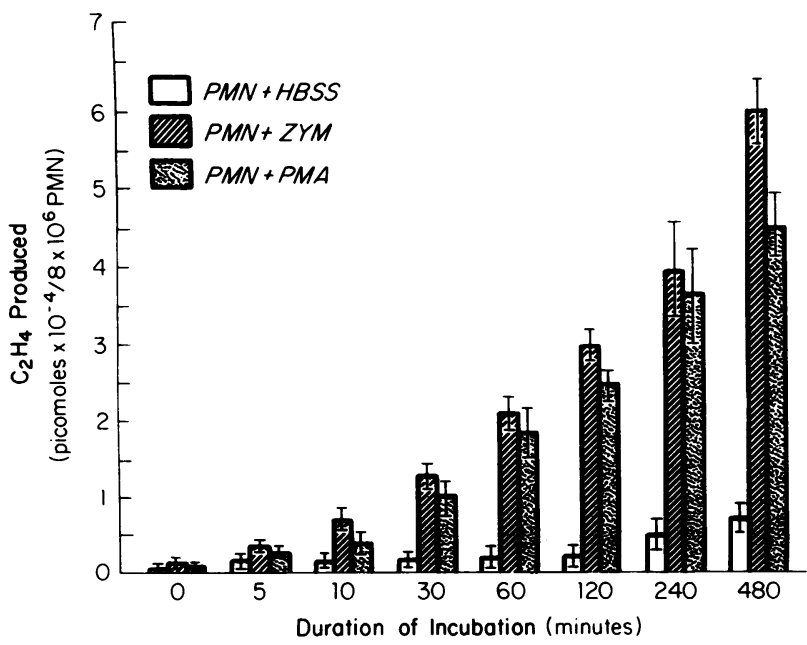

FIGURE 2 Generation of $\mathrm{C}_{2} \mathrm{H}_{4}$ by human $\mathrm{PMN}$ as a function of the duration of incubation. $\mathrm{C}_{2} \mathrm{H}_{4}$ production by stimulated human PMN continues for as long as $480 \mathrm{~min}$.
${ }^{14} \mathrm{CO}_{2}$ produced from incubations of $\mathrm{PMN}$ and opsonized zymosan (15).

\section{RESULTS}

Our initial goal was to compare the production of $\mathrm{C}_{2} \mathrm{H}_{4}$ from KMB by PMN stimulated with opsonized zymosan or PMA. Treatment of PMN with zymosan or PMA stimulated production of $\mathrm{C}_{2} \mathrm{H}_{4}$ from KMB. But doubling the number of PMN did not proportionately increase $\mathrm{C}_{2} \mathrm{H}_{4}$ generation (Fig. 1). This was not caused by a limitation of substrate because doubling the amount of KMB, zymosan, or PMA did not increase production of $\mathrm{C}_{2} \mathrm{H}_{4}$ (data not shown). Furthermore, prolonged incubation of stimulated $P M N$ led to increased production of $\mathrm{C}_{2} \mathrm{H}_{4}$ from $\mathrm{KMB}$, a process which continued for at least $8 \mathrm{~h}$ (Fig. 2). This differs from the patterns of $\mathrm{O}_{2}$ consumption, $\left[1-{ }^{14} \mathrm{C}\right]$ glucose oxidation, $\mathrm{H}_{2} \mathrm{O}_{2}$ generation and chemiluminescence at $37^{\circ} \mathrm{C}$ by stimulated PMN, all of which usually cease within $30 \mathrm{~min}$ (data not shown, 15, 33-35). These findings suggested that $\mathrm{C}_{2} \mathrm{H}_{4}$ arising from $\mathrm{KMB}$ and stimulated PMN might reflect processes in addition to the active cellular generation of $\cdot \mathrm{OH}$.

During the above investigations, we observed that PMN in the presence of PMA, but not zymosan, also produced $\mathrm{CH}_{4}$ (Table I). PMA preparations contained DMSO, which was used as a solvent for PMA (15). After addition of pure DMSO, zymosan-stimulated PMN also synthesized $\mathrm{CH}_{4}$ in a dose-dependent manner. Maximal $\mathrm{CH}_{4}$ production occurred over the range of $13-130 \mathrm{mM}$ DMSO. $\mathrm{CH}_{4}$ production from mixtures of zymosan- or PMA-treated PMN and DMSO

\section{TABLE I}

Effect of DMSO on the Production of $\mathrm{CH}_{4}$ by Human PMN Stimulated by Opsonized Zymosan or PMA

\begin{tabular}{lc}
\hline \multicolumn{1}{c}{ Test conditions* } & $\mathrm{CH}_{4}$ produced \\
\hline & pmol/20 min \\
PMN + PMA (dissolved in $2.6 \mathrm{mM}$ & $320 \pm 41 \quad(5)$ \\
DMSO) & $0(11)$ \\
PMN + zymosan & $120 \pm 110(8)$ \\
PMN + zymosan + DMSO (1.3 mM) & $990 \pm 180(8)$ \\
PMN + zymosan + DMSO (13 mM) & $1,080 \pm 175(16)$ \\
PMN + zymosan + DMSO (26 mM) & $1,190 \pm 210(19)$ \\
PMN + zymosan + DMSO (130 mM) & $1,020 \pm 240(8)$ \\
PMN + PMA + DMSO (13 mM) & $1,040 \pm 119(15)$ \\
PMN + PMA + DMSO (130 mM) & $240 \pm 42(12)$ \\
PMN + DMSO (13 mM) & $0(15)$ \\
PMN + HBSS & $4.1 \pm 0.9(6)$ \\
Zymosan + DMSO (13 mM) & $2.6 \pm 1.3(8)$ \\
PMA + DMSO (13 mM) & \\
\hline
\end{tabular}

* Each 3-ml tube contained in a final vol of $1 \mathrm{ml}, 8 \times 10^{6}$ PMN, $15 \mathrm{mg}$ opsonized Zymosan or $0.5 \mu \mathrm{g}$ PMA, and HBSS with or without DMSO and was incubated at $37^{\circ} \mathrm{C}$. $\ddagger$ Mean \pm SE (number of determinations). 
was approximately four times greater than from untreated PMN and DMSO. In addition, and in striking contrast to $\mathrm{C}_{2} \mathrm{H}_{4}$ production from KMB, increasing the number of zymosan- or PMA-stimulated PMN incubated with DMSO progressively increased $\mathrm{CH}_{4}$ production (Fig. 3). Moreover, $\mathrm{CH}_{4}$ generation by mixtures of stimulated PMN and DMSO plateaued in about $30 \mathrm{~min}$ (Fig. 4), a pattern in accord with the other metabolic responses of stimulated PMN.

\section{Reactions of DMSO or KMB with chemically or enzymatically generated forms of activated $\mathrm{O}_{2}$}

Because our goal was to determine the nature of the production of $\mathrm{CH}_{4}$ in systems containing phagocytes, we investigated $\mathrm{CH}_{4}$ production from chemical reactions known to produce activated forms of $\mathrm{O}_{2}$. These studies were performed in complete HBSS, at or near physiologic $\mathrm{pH}$ and using previously identified scavengers in concentrations that did not decrease cell viability or phagocytosis $(6-10,36-39)$. Additional studies showed that DMSO, thiourea and urea did not inhibit phagocytosis of radiolabeled bacteria by PMN (40) or decrease the ability of phagocytes to exclude trypan blue.

Xanthine/xanthine oxidase. It has been assumed that $\cdot \mathrm{OH}$ is generated by xanthine and xanthine oxidase through reaction of $\mathrm{O}_{\dot{2}}^{-}$and $\mathrm{H}_{2} \mathrm{O}_{2}$ and that this reaction is catalyzed by contaminating or enzyme-associated trace metals $(4,5,28)$ :

$$
\mathrm{O}_{\overline{2}}^{-}+\mathrm{H}_{2} \mathrm{O}_{2} \rightarrow \mathrm{O}_{2}+\mathrm{OH}^{-}+\cdot \mathrm{OH}
$$

In the presence of DMSO, the complete xanthine oxidase system produced large quantities of $\mathrm{CH}_{4}$ (Table II). $\mathrm{CH}_{4}$ production was decreased by SOD and nearly eliminated by catalase. Thiourea, a potent

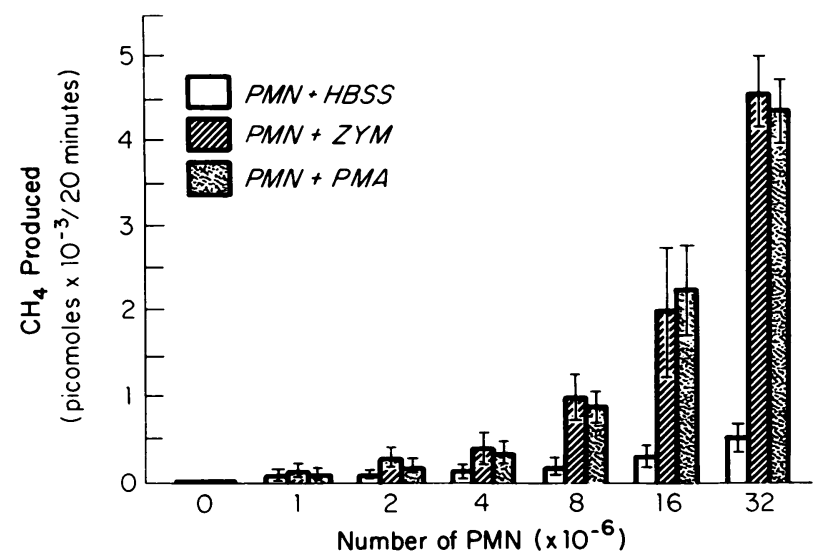

FIGURE 3 Generation of $\mathrm{CH}_{4}$ from $13 \mathrm{mM}$ DMSO by human $\mathrm{PMN}$ as a function of the number of $\mathrm{PMN}$. $\mathrm{CH}_{4}$ production progressively increases as the number of PMN are increased from 1 to $32 \times 10^{6}$.

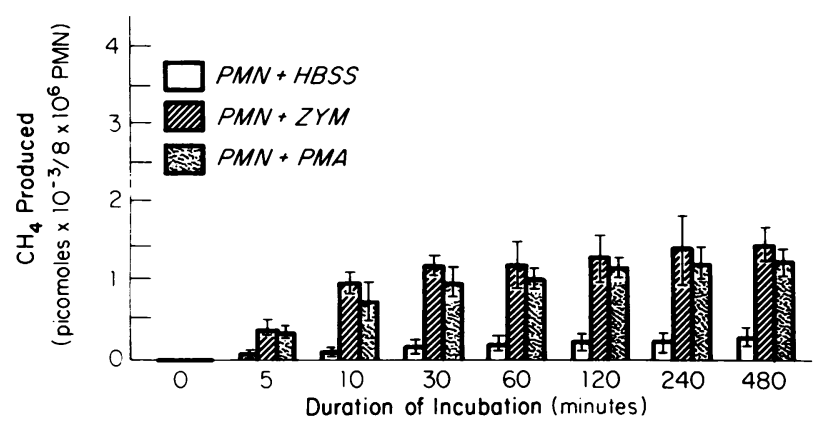

Figure 4 Generation of $\mathrm{CH}_{4}$ from 13 mM DMSO by human $\mathrm{PMN}$ as a function of the duration of incubation. $\mathrm{CH}_{4}$ production by stimulated PMN reaches maximal levels after 30-60 min of incubation.

scavenger of $\cdot \mathrm{OH}$, also decreased $\mathrm{CH}_{4}$ generation, whereas urea, an ineffective scavenger, had no effect. $\mathrm{C}_{2} \mathrm{H}_{4}$ was also formed from $\mathrm{KMB}$ by the xanthine/

TABLE II

Production of $\mathrm{CH}_{4}$ from DMSO or $\mathrm{C}_{2} \mathrm{H}_{4}$ from $\mathrm{KMB}$ during Reaction of Xanthine with Xanthine Oxidase

\begin{tabular}{|c|c|c|}
\hline Test conditions* & $\begin{array}{c}\mathrm{CH}_{4} \text { produced } \\
\text { from DMSO }(13 \mathrm{mM})\end{array}$ & $\begin{array}{c}\mathrm{C}_{2} \mathrm{H}_{4} \text { produced } \\
\text { from } \mathrm{KMB}(20 \mathrm{mM})\end{array}$ \\
\hline & \multicolumn{2}{|c|}{ pmol/20 min } \\
\hline & $2,029 \pm 182(21) \ddagger$ & $1,877 \pm 250$ \\
\hline \multicolumn{3}{|l|}{ Xanthine + XO } \\
\hline + SOD & $1,389 \pm 65 \quad(8) \S$ & $702 \pm 100(9) \S$ \\
\hline \multicolumn{3}{|l|}{ Xanthine + XO } \\
\hline+ catalase & $108 \pm 20(8) \S$ & $72 \pm 44 \quad(7) \S$ \\
\hline \multicolumn{3}{|l|}{ Xanthine $+\mathrm{XO}$} \\
\hline+ thiourea & $648 \pm 87 \quad(9) \S$ & $12 \pm 15(8) \S$ \\
\hline \multicolumn{3}{|l|}{ Xanthine + XO } \\
\hline+ urea & $2,196 \pm 200(9)$ & $1,710 \pm 52$ \\
\hline \multicolumn{3}{|l|}{ Xanthine + XO } \\
\hline + DMSO & ND" & $24(3) \S$ \\
\hline \multicolumn{3}{|l|}{ Xanthine + XO } \\
\hline KMB & $1676(3)$ & ND \\
\hline Xanthine & $12 \pm 14$ & $18 \pm 21 \quad(9) \S$ \\
\hline XO & $24 \pm 19$ & $9 \pm 5.2(9) \S$ \\
\hline HBSS & $1.4 \pm 18$ & $2.2 \pm 0.4(21)$ \\
\hline
\end{tabular}

$\mathrm{XO}$, xanthine oxidase.

* For assay of $\mathrm{CH}_{4}$ or $\mathrm{C}_{2} \mathrm{H}_{4}$ production, each 3-ml tube contained in a final vol of $1 \mathrm{ml} ; 4 \mathrm{mM}$ xanthine, $0.1 \mathrm{mM}$ EDTA, $0.025 \mathrm{U}$ xanthine oxidase, $100 \mu \mathrm{g} \mathrm{SOD} / \mathrm{ml}, 500 \mu \mathrm{g}$ catalase $/ \mathrm{ml}, 150 \mathrm{mM}$ thiourea, $150 \mathrm{mM}$ urea, $13 \mathrm{mM}$ DMSO, $20 \mathrm{mM} \mathrm{KMB}$ and/or phosphate-buffered HBSS, $\mathrm{pH}$ 7.8. In the absence of DMSO or KMB, xanthine, EDTA and xanthine oxidase did not make appreciable amounts of $\mathrm{CH}_{4}$ or $\mathrm{C}_{2} \mathrm{H}_{4}$. Acetaldehyde and xanthine oxidase produced $\mathrm{CH}_{4}$ in the absence of DMSO and was not used. Heat-inactivated, dialyzed SOD or heat-inactivated catalase did not significantly inhibit $\mathrm{CH}_{4}$ or $\mathrm{C}_{2} \mathrm{H}_{4}$.

$\$$ Mean $\pm \mathrm{SE}$ (number of determinations).

$\S$ Value significantly $(P<0.05)$ different from value with no inhibitor added.

"ND, not done. 
xanthine oxidase system and the above inhibitors had similar effects. When both DMSO and KMB were added, considerable $\mathrm{CH}_{4}$ was produced but only negligible amounts of $\mathrm{C}_{2} \mathrm{H}_{4}$ appeared. Thus, reactions with DMSO which produce $\mathrm{CH}_{4}$ take precedence over reactions with KMB which generate $\mathrm{C}_{2} \mathrm{H}_{4}$.

Because $\mathrm{O}_{2}^{-}$and $\mathrm{H}_{2} \mathrm{O}_{2}$ are also produced by the xanthine/xanthine oxidase system, additional experiments were performed to determine if $\mathrm{O}_{\overline{2}}^{-}$or $\mathrm{H}_{2} \mathrm{O}_{2}$ reacted directly with DMSO or KMB to cause liberation of $\mathrm{CH}_{4}$ or $\mathrm{C}_{2} \mathrm{H}_{4}$. First, neither DMSO (13-130 mM) nor KMB (2-20 mM) inhibited $\mathrm{O}_{\bar{z}}^{-}$-dependent reduction of cytochrome $c$ by the complete xanthine oxidase system (41), whereas SOD nearly blocked this reaction (data not shown). Second, in the presence of DMSO or $\mathrm{KMB}, \mathrm{H}_{2} \mathrm{O}_{2}(0.003-30 \mu \mathrm{M})$ failed to generate detectable amounts of $\mathrm{CH}_{4}$ or $\mathrm{C}_{2} \mathrm{H}_{4}$ (Table III). Thus, neither $\mathrm{O}_{\overline{2}}^{\overline{2}}$ nor $\mathrm{H}_{2} \mathrm{O}_{2}$ reacts directly with DMSO or $\mathrm{KMB}$ to form $\mathrm{CH}_{4}$ or $\mathrm{C}_{2} \mathrm{H}_{4}$.

$\mathrm{Fe} / \mathrm{EDTA} / \mathrm{H}_{2} \mathrm{O}_{2}$. Another system which generates - $\mathrm{OH}$ involves the reaction of ferrous $\left(\mathrm{Fe}^{++}\right)$sulfate/EDTA with $\mathrm{H}_{2} \mathrm{O}_{2}$ (42):

$$
\mathrm{Fe}^{++} / \mathrm{EDTA}+\mathrm{H}_{2} \mathrm{O}_{2} \rightarrow \mathrm{Fe}^{+++} / \mathrm{EDTA}+\mathrm{OH}^{-}+\cdot \mathrm{OH}
$$

This reaction produced large quantities of $\mathrm{CH}_{4}$ from DMSO (Table III). $\mathrm{CH}_{4}$ production was not diminished by SOD but was greatly decreased by catalase, implicating an involvement of $\mathrm{H}_{2} \mathrm{O}_{2}$. However, as

TABLE III

Production of $\mathrm{CH}_{4}$ during Reaction of $\mathrm{Fe}^{++}$with $\mathrm{H}_{2} \mathrm{O}_{2}$

\begin{tabular}{lc}
\hline \multicolumn{1}{c}{ Test conditions* } & $\mathrm{CH}_{4}$ produced \\
\hline & pmoli20 min \\
& $11 \pm 1.3 \quad(38) \ddagger$ \\
$\mathrm{Fe}^{++}+\mathrm{H}_{2} \mathrm{O}_{2}$ & $36,101 \pm 1,885(35)$ \\
$\mathrm{Fe}^{++}+\mathrm{H}_{2} \mathrm{O}_{2}+\mathrm{DMSO}$ & $\mathrm{ND}$ \\
$\mathrm{Fe}^{++}+\mathrm{H}_{2} \mathrm{O}_{2}+\mathrm{SOD}$ & $38,528 \pm 2,540(12)$ \\
$\mathrm{Fe}^{++}+\mathrm{H}_{2} \mathrm{O}_{2}+\mathrm{SOD}+\mathrm{DMSO}$ & $\mathrm{ND}$ \\
$\mathrm{Fe}^{++}+\mathrm{H}_{2} \mathrm{O}_{2}+$ catalase & $12,428 \pm 1,286(12) \S$ \\
$\mathrm{Fe}^{++}+\mathrm{H}_{2} \mathrm{O}_{2}+$ catalase + DMSO & $\mathrm{ND}$ \\
$\mathrm{Fe}^{++}+\mathrm{H}_{2} \mathrm{O}_{2}+\mathrm{KMB}$ & $18 \pm 9$ \\
$\mathrm{Fe}^{++}+\mathrm{DMSO}$ & $1.4 \pm 1.8 \quad(32)$ \\
$\mathrm{H}_{2} \mathrm{O}_{2}+\mathrm{DMSO}$ & $1.8 \pm 1.3 \quad(26)$ \\
$\mathrm{HBSS}+$ DMSO &
\end{tabular}

* For assay of $\mathrm{CH}_{4}$ production, each 3-ml tube contained in a final vol of $1 \mathrm{ml} ; 11 \mathrm{mM}$ ferrous sulfate, $1 \mathrm{mM}$ EDTA, 30 $\mu \mathrm{M} \mathrm{H}_{2} \mathrm{O}_{2}, 100 \mu \mathrm{g} \mathrm{SOD} / \mathrm{ml}, 500 \mu \mathrm{g}$ catalase $/ \mathrm{ml} 13 \mathrm{mM}$ DMSSO, $20 \mathrm{mM} \mathrm{KMB}$ and/or phosphate-buffered HBSS, pH 7.8. $\mathrm{FeSO}_{4}$ reacted directly with $\mathrm{KMB}$ to form $\mathrm{C}_{2} \mathrm{H}_{4}$, so studies of $\mathrm{C}_{2} \mathrm{H}_{4}$ production were not performed. Autoclaved, dialyzed SOD or heat-inactivated catalase did not significantly inhibit $\mathrm{CH}_{4}$ production.

\$ Mean $\pm \mathrm{SE}$ (number of determinations).

$\$$ Value significantly $(P<0.05)$ different from value with no inhibitor.

"ND, not done. previously shown, $\mathrm{H}_{2} \mathrm{O}_{2}$ and DMSO alone did not produce $\mathrm{CH}_{4}$.

Generation of $\mathrm{CH}_{4}$ from DMSO or $\mathrm{C}_{2} \mathrm{H}_{4}$ from KMB by stimulated phagocytes

$\mathrm{CH}_{4}$ produced by the above chemical reactions was almost certainly derived from DMSO. To determine that this was also true for complex cellular systems, we performed preliminary studies with stimulated PMN using $\mathrm{d}_{6}$-DMSO. These studies confirmed that the $\mathrm{CH}_{4}$ produced did indeed come from DMSO. The mass spectrum of the $\mathrm{CH}_{4}$ formed showed a mol wt of 19 , which corresponds to $\mathrm{d}_{3}-\mathrm{CH}_{4}$. This agrees with the published mass spectrum of $\mathrm{d}_{3}-\mathrm{CH}_{4}$ (base peak $=\mathrm{m} / \mathrm{e} 19, \mathrm{~m} / \mathrm{e} 17=51.1 \%[29]$ ).

We also performed studies that indicated that intact PMN with normal oxidative metabolic activities were needed for the generation of $\mathrm{CH}_{4}$ from DMSO. These studies showed that appreciable amounts of $\mathrm{CH}_{4}$ were not produced from mixtures of DMSO and zymosanor PMA-stimulated, heat-killed or CGD PMN (data not shown).

Studies with scavengers of $\mathrm{O}_{2}^{-}$or $\mathrm{H}_{2} \mathrm{O}_{2}$ confirmed that both species contributed to the production of $\mathrm{CH}_{4}$ from DMSO or $\mathrm{C}_{2} \mathrm{H}_{4}$ from KMB by stimulated PMN (Table IV). Furthermore, thiourea, a purported -OH scavenger, but not urea, practically abolished $\mathrm{CH}_{4}$ generation, while decreasing $\mathrm{C}_{2} \mathrm{H}_{4}$ production $\sim 70-80 \%$. Another presumed scavenger of $\cdot \mathrm{OH}$, tryptophane, also eliminated $\mathrm{CH}_{4}$ or $\mathrm{C}_{2} \mathrm{H}_{4}$ production. other suspected scavengers of $\cdot \mathrm{OH}$, sodium benzoate, mannitol, or ethanol, although not as effective as thiourea or tryptophane, were more efficient in systems containing DMSO (50-60\% inhibition) that KMB (20-35\%). Azide or histidine also decreased $\mathrm{CH}_{4}$ or $\mathrm{C}_{2} \mathrm{H}_{4}$ production by stimulated $\mathrm{PMN}$.

Zymosan- or PMA-treated human MN also produced $\mathrm{CH}_{4}$ from DMSO (Table V). SOD or catalase inhibited $\mathrm{CH}_{4}$ production by $\sim 25-45 \%$. The production of $\mathrm{CH}_{4}$ by zymosan- or PMA-stimulated MN was approximately one-half as much per cell as the $\mathrm{CH}_{4}$ generation by stimulated PMN. As expected, stimulated MN from patients with CGD did not produce increased amounts of $\mathrm{CH}_{4}$.

Zymosan- or PMA-treated human AM also generated $\mathrm{CH}_{4}$ from DMSO, a process inhibited by SOD, catalase, or thiourea (Table V). Generation of $\mathrm{CH}_{4}$ by $\mathrm{AM}$ was approximately one-sixth as great per cell as PMN and about one-third that of peripheral blood MN.

\section{DISCUSSION}

Considerable interest has focused on $\cdot \mathrm{OH}$ production by phagocytes becaúse this may be important in their bactericidal or cytotoxic activities $(43,44)$. However, the techniques for measurement of $\cdot \mathrm{OH}$ production 


\section{TABLE IV}

Effect of Scavengers on the Production of $\mathrm{CH}_{4}$ from DMSO or $\mathrm{C}_{2} \mathrm{H}_{4}$ from $\mathrm{KMB}$ by PMN Stimulated by Opsonized Zymosan or PMA

\begin{tabular}{|c|c|c|c|c|}
\hline \multirow[b]{2}{*}{ Test conditions: inhibitor added* } & \multicolumn{2}{|c|}{$\mathrm{CH}_{4}$ production } & \multicolumn{2}{|c|}{$\mathrm{C}_{2} \mathrm{H}_{4}$ production } \\
\hline & $\begin{array}{c}\text { Zymosan- } \\
\text { stimulated } \\
\text { PMN }\end{array}$ & $\begin{array}{l}\text { PMA- } \\
\text { stimulated } \\
\text { PMN }\end{array}$ & $\begin{array}{c}\text { Zymosan- } \\
\text { stimulated } \\
\text { PMN }\end{array}$ & $\begin{array}{l}\text { PMA- } \\
\text { stimulated } \\
\text { PMN }\end{array}$ \\
\hline & \multicolumn{4}{|c|}{ \% inhibition } \\
\hline $\mathrm{SOD}, 100 \mu \mathrm{g} / \mathrm{ml}$ & $84 \pm 12(8) \ddagger$ & $91 \pm 9.1(8)$ & ND" & ND \\
\hline $\mathrm{SOD}, 10 \mu \mathrm{g} / \mathrm{ml}$ & $82 \pm 9.6(8)$ & $88 \pm 12(8)$ & $92 \pm 8.4(6)$ & $90 \pm 6.4(6)$ \\
\hline $\mathrm{SOD}, 1.0 \mu \mathrm{g} / \mathrm{ml}$ & $79 \pm 13(8)$ & $78 \pm 10(8)$ & ND & ND \\
\hline SOD, $10 \mu \mathrm{g} / \mathrm{ml}$, inactivated & $12 \pm 0.9(6)$ & $21 \pm 2.1(8)$ & ND & ND \\
\hline Catalase, $1000 \mu \mathrm{g} / \mathrm{ml}$ & $51 \pm 19$ & $52 \pm 8.2(8)$ & ND & ND \\
\hline Catalase, $250 \mu \mathrm{g} / \mathrm{ml}$ & $48 \pm 9.2(8)$ & $57 \pm 16(8)$ & $74 \pm 11(6)$ & $71 \pm 9.3(6)$ \\
\hline Catalase, $100 \mu \mathrm{g} / \mathrm{ml}$ & $36 \pm 12(8)$ & $42 \pm 19(8)$ & ND & ND \\
\hline \multicolumn{5}{|l|}{ Catalase, $500 \mu \mathrm{g} / \mathrm{ml}$, heat } \\
\hline inactivated & $0(8)$ & $4.2 \pm 3.8(8)$ & ND & ND \\
\hline Albumin $1 \%$ & $2.6 \pm 0.8(8)$ & $3.9 \pm 1.4(4)$ & $1.4 \pm 0.9(5)$ & $2.9 \pm 1.6(4)$ \\
\hline Thiourea, $15 \mathrm{mM}$ & $102 \pm 4.1(5)$ & $96 \pm 5.8(7)$ & $72 \pm 15(6)$ & $81 \pm 11$ \\
\hline Thiourea, $1.5 \mathrm{mM}$ & $90 \pm 9.8(5)$ & $92 \pm 9.8(5)$ & ND & ND \\
\hline Urea, $15 \mathrm{mM}$ & $4.2 \pm 3.6(7)$ & $3.1 \pm 2.6(4)$ & $9.1 \pm 3.1(6)$ & $3.6 \pm 1.8(5)$ \\
\hline Urea, $1.5 \mathrm{mM}$ & $0.4 \pm 0.6(5)$ & $6.4 \pm 10$ & ND & ND \\
\hline Tryptophane, $1.0 \mathrm{mM}$ & $108 \pm 14$ & $100 \pm 12(6)$ & $94 \pm 14$ & $98 \pm 26(4)$ \\
\hline Tryptophane, $0.5 \mathrm{mM}$ & $52 \pm 11$ & $42 \pm 9.1(6)$ & ND & ND \\
\hline Sodium benzoate, $20 \mathrm{mM}$ & $46 \pm 9.1(5)$ & $42 \pm 11$ & $26 \pm 9.2(5)$ & $34 \pm 16$ \\
\hline Sodium benzoate, $2 \mathrm{mM}$ & $36 \pm 16(5)$ & $42 \pm 11(5)$ & ND & ND \\
\hline Mannitol, $50 \mathrm{mM}$ & $74 \pm 14$ & $59 \pm 12(5)$ & $34 \pm 6.8(5)$ & $26 \pm 9.4(7)$ \\
\hline Mannitol, $5 \mathrm{mM}$ & $52 \pm 6.4(5)$ & $47 \pm 11$ & ND & ND \\
\hline Ethanol, $40 \mathrm{mM}$ & $64 \pm 14(5)$ & $59 \pm 14(5)$ & ND & ND \\
\hline Ethanol, $20 \mathrm{mM}$ & $46 \pm 11$ & ND & $34 \pm 15$ & $35 \pm 11(6)$ \\
\hline Histidine, $0.1 \mathrm{mM}$ & $84 \pm 26$ & $84 \pm 15(4)$ & $94 \pm 15(6)$ & ND \\
\hline Azide, $1.0 \mathrm{mM}$ & $89 \pm 15(6)$ & $66 \pm 14$ & $94 \pm 14$ & $92 \pm 14$ \\
\hline Azide, $0.1 \mathrm{mM}$ & $78 \pm 11$ & ND & ND & ND \\
\hline
\end{tabular}

* Each 3-ml tube contained in a final vol of $\mathrm{i} \mathrm{ml} ; 8 \times 10^{6} \mathrm{PMN}$ with $15 \mathrm{mg}$ Zymosan or 0.5 $\mu \mathrm{g}$ PMA, the inhibitors and/or HBSS with $13 \mathrm{mM}$ DMSO or $2 \mathrm{mM} \mathrm{KMB}$. Base line gas production in the absence of inhibitors was $\sim 1,000 \mathrm{pmol} \mathrm{CH}_{4}$ from DMSO/20 $\mathrm{min}$ or $\sim 10,000$ pmol $\mathrm{C}_{2} \mathrm{H}_{4}$ from $\mathrm{KMB} / 20$ min for Zymosan or PMA-stimulated PMN.

$\ddagger$ Mean \pm SE (number of determinations).

$\$$ Results of mean inhibition calculated from $\%$ inhibition $=\left(\mathrm{CH}_{4}\right.$ without inhibitor $-\mathrm{CH}_{4}$ with inhibitor/ $\mathrm{CH}_{4}$ without inhibitor) $\times 100$.

"ND, not done.

by phagocytes have not been totally satisfactory because of vagaries in specificity or incompatibilities with biological substances. We are reporting a new approach for the measurement of $\cdot \mathrm{OH}$ generation by phagocytes, namely the generation of $\mathrm{CH}_{4}$ from DMSO.

Previous investigations suggested that DMSO might be a potent scavenger of $\cdot \mathrm{OH}(16-24)$, that reaction of DMSO with titanium chloride and $\mathrm{H}_{2} \mathrm{O}_{2}$ produces methyl radical (22), and that $\mathrm{CH}_{4}$ might be produced by reaction of $\cdot \mathrm{OH}$ with DMSO $(20,21,25)$. However, the specificity of the reaction of $\cdot \mathrm{OH}$ with DMSO to produce $\mathrm{CH}_{4}$ and its potential as a detection system for $\cdot \mathrm{OH}$ have not previously been determined. The rate constant for reaction of $\cdot \mathrm{OH}$ with DMSO $\left(5.8 \times 10^{9} \mathrm{M}^{-1}\right.$ $\left.\mathrm{s}^{-1}\right)$ indicates rapid reaction of the two compounds $(16,45)$.

$$
\begin{gathered}
\left(\mathrm{CH}_{3}\right)_{2} \mathrm{SO}+\cdot \mathrm{OH} \rightarrow\left(\mathrm{CH}_{3}\right)_{2} \mathrm{~S} \rightarrow \cdot \mathrm{CH}_{3}+\mathrm{CH}_{3} \mathrm{SO}_{2} \mathrm{H} \\
\qquad \mathrm{CH}_{3}+\mathrm{RH} \rightarrow \mathrm{CH}_{4}+\mathrm{R} .
\end{gathered}
$$

This reaction is consistent with the observation that - $\mathrm{OH}$ attacks dialkyl sulfoxides at sulfur rather than by hydrogen abstraction (46). Furthermore, our mass spectral studies of the $\mathrm{CH}_{4}$ formed by stimulated 
TABLE V

Production of $\mathrm{CH}_{4}$ from DMSO by Normal or CGD MN and Normal AM

Stimulated by Opsonized Zymosan or PMA

\begin{tabular}{|c|c|c|c|}
\hline \multirow[b]{2}{*}{ Test conditions* ${ }^{*}$} & \multicolumn{3}{|c|}{$\mathrm{CH}_{4}$ produced from DMSO } \\
\hline & Normal MN & CGD MN & Normal AM \\
\hline & \multicolumn{3}{|c|}{ pmol/20 min } \\
\hline Cells + HBSS & $150 \pm 43 \quad(12) \ddagger$ & $88 \pm 28(6)$ & $120 \pm 28(8) !$ \\
\hline Cells + zymosan & $1,080 \pm 290(8) \S$ & $120 \pm 42(6)$ & $320 \pm 85(6) \S$ \\
\hline Cells + SOD + zymosan & $420(3)-61 \%$ & ND" & $110(3)-66 \%$ व \\
\hline Cells + catalase + zymosan & $510(3)-53 \%$ & ND & $180(3)-44 \%$ \\
\hline Cells + thiourea + zymosan & $150(3)-86 \%$ & ND & $135(3)-58 \%$ \\
\hline Cells + tryptophan + zymosan & $160(3)-85 \%$ & ND & ND \\
\hline Cells + sodium benzoate + zymosan & $540(3)-50 \%$ & ND & ND \\
\hline Cells + ethanol + zymosan & $560(3)-48 \%$ & ND & ND \\
\hline Cells + PMA & $920 \pm 106(8) \S$ & $125 \pm 38(6)$ & $280 \pm 60(6)$ \\
\hline Cells + SOD + PMA & $440(3)-52 \%$ & ND & $120(3)-57 \%$ \\
\hline Cells + catalase + PMA & $385(3)-58 \%$ & ND & $160(3)-43 \%$ \\
\hline Cells + thiourea + PMA & $190(3)-79 \%$ & ND & $100(2)-64 \%$ \\
\hline Cells + tryptophane + PMA & $180(3)-80 \%$ & ND & ND \\
\hline Cells + sodium benzoate + PMA & $410(3)-55 \%$ & ND & ND \\
\hline Cells + ethanol + PMA & $490(3)-47 \%$ & ND & ND \\
\hline
\end{tabular}

* Each 3-ml tube contained a final vol of $1 \mathrm{ml}$, which included $20 \times 10^{6} \mathrm{MN}, 15 \mathrm{mg}$ zymosan or $0.5 \mu \mathrm{g}$ PMA, and $100 \mu \mathrm{g}$ SOD, $500 \mu \mathrm{g}$ catalase, $15 \mathrm{mM}$ thiourea, $1 \mathrm{mM}$ tryptophan, $20 \mathrm{mM}$ sodium benzoate, $40 \mathrm{mM}$ ethanol and/or HBSS with $13 \mathrm{mM}$ DMSO. $\ddagger$ Mean \pm SE (number of determinations).

$\$$ Value significantly different $(P<0.05)$ from value with HBSS alone.

"ND, not done.

I \% inhibition from value without inhibitor.

phagocytes (and by $\mathrm{Fe}^{++} / \mathrm{EDTA} / \mathrm{H}_{2} \mathrm{O}_{2}$, data not presented) showed that $\mathrm{d}_{3}-\mathrm{CH}_{4}$ was produced from $\mathrm{d}_{6}$-DMSO. This is the expected finding because it is known that methyl radicals do not abstract hydrogen from DMSO in solution (47); abstraction of hydrogen from $\mathrm{d}_{6}$-DMSO would yield $\mathrm{d}_{4}-\mathrm{CH}_{4}$. This was not observed.

The results of the present investigation indicate that generation of $\mathrm{CH}_{4}$ from DMSO is a relatively specific result of reaction with $\cdot \mathrm{OH}$ and that this approach may prove useful for evaluation of the production of $\cdot \mathrm{OH}$ in biological systems. DMSO does not spontaneously form $\mathrm{CH}_{4}$ (Table I) and chemical systems (xanthine and xanthine oxidase or $\mathrm{Fe}^{++} /$EDTA and $\mathrm{H}_{2} \mathrm{O}_{2}$ ) known to give rise to $\cdot \mathrm{OH}$ produced large amounts of $\mathrm{CH}_{4}$ from DMSO (Tables II and III). Whereas production of $\mathrm{CH}_{4}$ from DMSO by xanthine oxidase is decreased by SOD or catalase (implicating participation of $\mathrm{O}_{\bar{i}}$ and $\left.\mathrm{H}_{2} \mathrm{O}_{2}\right), \mathrm{O}_{2}^{-}$or $\mathrm{H}_{2} \mathrm{O}_{2}$ alone do not appear to produce $\mathrm{CH}_{4}$ from DMSO. If $\mathrm{O}_{\overline{2}}^{-}$reacted directly with DMSO to make $\mathrm{CH}_{4}$, catalase would not inhibit the generation of $\mathrm{CH}_{4}$ by xanthine and xanthine oxidase (28). In addition, DMSO does not inhibit xanthine/xanthine oxidasemediated reduction of ferricytochrome $c$, a reaction that is dependent on $\mathrm{O}_{\dot{2}}^{-}(41)$. Furthermore, multiple concentrations of $\mathrm{H}_{2} \mathrm{O}_{2}$ and DMSO do not form $\mathrm{CH}_{4}$. Thus, whereas large quantities of $\mathrm{CH}_{4}$ are produced from DMSO by $\cdot \mathrm{OH}$ generating systems, there is probably little or no production of $\mathrm{CH}_{4}$ from DMSO in the presence of $\mathrm{O}_{\overline{2}}^{-}$or $\mathrm{H}_{2} \mathrm{O}_{2}$ alone. Although technical difficulties with the generation and measurement of pure ${ }^{1} \mathrm{O}_{2}$ make it very difficult to determine if reaction of ${ }^{1} \mathrm{O}_{2}$ with DMSO to produce $\mathrm{CH}_{4}$ or with KMB to generate $\mathrm{C}_{2} \mathrm{H}_{4}$, preliminary studies addressing this question (employing several ${ }^{1} \mathrm{O}_{2}$ generators including rose bengal) indicte that DMSO is unreactive with ${ }^{1} \mathrm{O}_{2}$. Thus, the evidence presented favors the proposition that $\mathrm{CH}_{4}$ production arises predominantly from reaction of $\cdot \mathrm{OH}$ with DMSO.

Comparison of the production of $\mathrm{CH}_{4}$ from DMSO or $\mathrm{C}_{2} \mathrm{H}_{4}$ from KMB further supports the possibility that reaction of $\cdot \mathrm{OH}$ with DMSO might be a more effective approach for evaluation of the generation of - OH. First, DMSO appears to be a more effective scavenger of $\cdot \mathrm{OH}$ than $\mathrm{KMB}$. In mixtures containing the complete xanthine oxidase system with both DMSO and $\mathrm{KMB}$ the production of $\mathrm{CH}_{4}$ from DMSO was nearly normal, while there was no appreciable generation of $\mathrm{C}_{2} \mathrm{H}_{4}$ from KMB. Second, production of $\mathrm{CH}_{4}$ from DMSO by stimulated phagocytic cells 
increases according to the number of PMN added and the kinetics of $\mathrm{CH}_{4}$ production reflect those of other $\mathrm{O}_{2}$-dependent metabolic events. In contrast, the generation of $\mathrm{C}_{2} \mathrm{H}_{4}$ from KMB does not increase with the number of $\mathrm{PMN}$ present or follow expected patterns, producing considerable amounts of $\mathrm{C}_{2} \mathrm{H}_{4}$ for as much as $8 \mathrm{~h}$, long after other metabolic activities of the cells have ceased. A self-propagating event, known to occur between certain oxygen intermediates $\left({ }^{1} \mathrm{O}_{2}\right)$ and lipids might account for this prolonged production of $\mathrm{C}_{2} \mathrm{H}_{4}$ from $\mathrm{KMB}$ by metabolically exhausted PMN. KMB may also react with cell-associated Fe to produce $\mathrm{C}_{2} \mathrm{H}_{4}$. We find that large amounts of $\mathrm{C}_{2} \mathrm{H}_{4}$ are generated from KMB by the EDTA chelate of $\mathrm{Fe}^{++}$(data not presented). Third, the results show that intact cells or cells with normal oxidative metabolic capabilities are necessary for $\mathrm{CH}_{4}$ generation from DMSO. Heat-killed cells and PMN or MN from patients with CGD did not make appreciable amounts of $\mathrm{CH}_{4}$ from DMSO. Fourth, DMSO was not toxic to the cells and did not inhibit uptake of bacteria by PMN. In addition, the results of investigations with purported scavengers of various $\mathrm{O}_{2}$ metabolites support the relative specificity of the reaction of DMSO with - OH. However, it should be noted that, as with most inhibitor studies, the specificity of these agents is not absolute and, the mechanism of their action is open to question in many cases.

Hydroxyl radical is considered a part of the mechanism which phagocytic cells use to kill ingested microorganisms (2). The assumed role of $\cdot \mathrm{OH}$ in the microbicidal processes of phagocytes is supported by the decreased bactericidal activities of PMN that have been treated with sodium benzoate, a scavenger of . $\mathrm{OH}(3)$, and the amelioration by $\cdot \mathrm{OH}$ scavengers of the bactericidal actions of chemical systems that generate activated forms of $\mathrm{O}_{2}(48-50)$. Hydroxyl radical may also participate in phagocyte-mediated cytotoxicity.

In addition to its presumed role in the bactericidal and cytotoxic activities of phagocytes, $\cdot \mathrm{OH}$ may participate in many other important biological reactions $(43$, 44). The basis for implicating $\cdot \mathrm{OH}$ in these diverse processes has often been that DMSO, as well as other scavengers of $\cdot \mathrm{OH}$, alter expected responses. For example, DMSO decreases radiation injury (23), alloxaninduced diabetes (19), arthritis (51), contact dermatitis (52), and noninfectious or neoplastic inflammation of the bladder (53). DMSO has also been used frequently as a solvent $(15,52)$, and as a cryopreservative for leukocytes (54), platelets (55), erythrocytes (56), and other mammalian cells (57). Whereas the precise mechanism underlying these and many other actions of DMSO are unknown, many may involve the scavenging $\cdot \mathrm{OH}$ by DMSO. This is a particularly appealing possibility in the case of the anti-inflammatory effects of DMSO.
Although most organisms have very active enzymes for the catabolism of $\mathrm{H}_{2} \mathrm{O}_{2}$ and $\mathrm{O}_{\overline{2}}$ (precursors of $\cdot \mathrm{OH}$ ), there are no direct enzymatic mechanisms for clearance of highly reactive $\cdot \mathrm{OH}$. Thus, the reaction of DMSO with $\cdot \mathrm{OH}$ may explain the potent anti-inflammatory action of DMSO. DMSO has an extremely low toxicity, can be easily administered by oral, topical, and other routes, is rapidly distributed throughout the body, and readily penetrates cells $(58-61)$. Thus, the generation of $\mathrm{CH}_{4}$ by reaction of $\cdot \mathrm{OH}$ with DMSO should be useful for detecting and measuring the production of $\cdot \mathrm{OH}$ both in vitro and in vivo and determining its biological effects.

\section{ACKNOWLEDGMENTS}

We are indebted to Ms. Jonalyn Kunce, Ms. Betsy Nelson, and Ms. Elaine Berger for excellent technical assistance. We were greatly aided by discussions with Dr. Gerald Cohen.

This work was supported in part by grants from the Minnesota and American Heart Associations, the National Foundation of the March of Dimes, and National Institutes of Health HL 16833, N01-AM-6-2214 and R01-HL-24248.

\section{REFERENCES}

1. Babior, B. M. 1978. Oxygen-dependent microbial killing by phagocytes. N. Engl. J. Med. 298: 659-668, 721-725.

2. Klebanoff, S. J. 1975. Antimicrobial mechanisms in neutrophilic polymorphonuclear leukocytes. Semin. Hematol. 12: $117-142$.

3. Johnston, R. B., Jr., B. B. Keele, Jr., H. P. Misra, J. E. Lehmeyer, L. S. Webb, R. L. Baehner, and K. V. Rajagopolan. 1975. The role of superoxide anion generation in phagocytic bactericidal activity. Studies with normal and chromic granulomatous disease leukocytes. J. Clin. Invest. 55: 1357-1372.

4. McCord, J. M., and E. D. Day, Jr. 1978. Superoxidedependent production of hydroxyl radical catalyzed by iron-EDTA complex. Febs. (Fed. Eur. Biochem. Soc.) Lett. 86: $139-142$.

5. Cohen, G. 1977. In defense of Haber-Weiss. In Superoxide and Superoxide Dismutases. J. M. McCord and I. Fridovich, editors. Academic Press, Inc. New York. 317-321.

6. Tauber, A. I., and B. M. Babior. 1977. Evidence for hydroxyl radical production by human neutrophils. J. Clin. Invest. 60: $374-381$.

7. Weiss, S. J., G. W. King, and A. F. LoBuglio. 1977. Evidence for hydroxyl radical generation by human monocytes. J. Clin. Invest. 60: 370-373.

8. Weiss, S. J., P. K. Rustagi, and A. F. LoBuglio. 1978. Human granulocyte generation of hydroxyl radical. J. Exp. Med. 147: 316-323.

9. Hoidal, J. R., G. D. Beall, and J. E. Repine. 1979. Production of hydroxyl radical by human alveolar macrophages. Infect. Immun. In press.

10. Klebanoff, S. J., and H. Rosen. 1978. Ethylene formation by polymorphonuclear leukocytes. Role of myeloperoxidase. J. Exp. Med. 148: 490-506.

11. Pryor, W. A., and R. H. Tang. 1978. Ethylene formation from methional. Biochem. Biophys. Res. Commun. 81: 498-503.

12. Yang, S. F. 1969. Further studies on ethylene formation from $\alpha$-keto-methylthiobutyric acid or $\beta$-methylthiopropionaldehyde by peroxidase in the presence of sulfite and oxygen. J. Biol. Chem. 244: 4360-4365. 
13. Yang, S. F. 1967. Biosynthesis of ethylene. Ethylene formation from methional by horseradish peroxidase. Arch. Biochem. Biophys. 122: 481-486.

14. Bors, W., E. Lengfelder, M. Saran, C. Fuchs, and C. Michel. 1976. Reactions of oxygen radical species with methional: a pulse radiolysis study. Biochem. Biophys. Res. Commun. 70: 81-87.

15. Repine, J. E., J. G. White, C. C. Clawson, and B. M. Holmes. 1974. The influence of phorbol myristate acetate on the metabolism and ultrastructure of neutrophils in chronic granulomatous disease. J. Clin. Invest. 54: 83-90.

16. Reuvers, A. P., C. L. Greenstock, J. Borsa, and J. D. Chapman. 1973. Studies on the mechanisms of chemical radioprotection by dimethyl sulfoxide. Int. J. Radiat. Biol. Relat. Stud. Phys. Chem. Med. 24: 533-536.

17. Panganamala, R. V., H. M. Sharma, R. E. Heikkila, J. C. Geer, and D. G. Cornwell. 1976. Role of hydroxyl radical scavengers dimethyl sulfoxide, alcohols, and methional in the inhibition of prostaglandin synthesis. Prostaglandins. 11: 599-607.

18. Cederbaum, A. I., E. Dicker, E. Rubin, and G. Cohen. 1977. The effect of dimethylsulfoxide and other hydroxyl radical scavengers on the oxidation of ethanol by rat liver microsomes. Biochem. Biophys. Res. Commun. 78: 12541262.

19. Heikkila, R. E., B. Winston, G. Cohen, and H. Barden. 1976. Alloxan-induced diabetes - evidence for hydroxyl radical as a cytotoxic intermediate. Biochem. Pharmacol. 25: 1085-1093.

20. Miller, J. S., and D. G. Cornwell. 1978. The role of cryoprotective agents as hydroxyl radical scavengers. Cryobiology. 15: 585-588.

21. Brownlee, N. R., J. Huttner, R. V. Panganamala, and D. G. Cornwell. 1977. Role of vitamin $\mathrm{E}$ in glutathione-induced oxidant stress: methemoglobin, lipid peroxidation, and hemolysis. J. Lipid Res. 18: 635-644.

22. Damerau, W., G. Labmann, and K. Lohs. 1969. Zur Einwirk ung von hydroxylradikalen auf dimethylsulfoxid. Z. Chem. 9: 343-344.

23. Ashwood-Smith, M. J. 1975. Current concepts concerning radioprotective and cryoprotective properties of dimethylsulfoxide in cellular systems. Ann. N. Y. Acad. Sci. 243: 246-256.

24. Chapman, J. D., A. P. Reuvers, J. Borsa, and C. L. Greenstock. 1973. Chemical radioprotection and radiosensitization of mammalian cells growing in vitro. Radiat. Res. 56: 291-306.

25. Cohen, G., and A. Cederbaum. 1979. Chemical evidence for production of hydroxyl radicals during microsomal electron transfer. Science (Wash, D. C.) 204: 66-68.

26. Repine, J. E., and C. C. Clawson. 1978. Influence of surface proteins and separation techniques on neutrophil unstimulated and stimulated locomotion in vitro. J. Reticuloendothel. Soc. 24: 217-224.

27. Repine, J. E., C. C. Clawson, and P. S. Friend. 1977. Influence of a deficiency of the second component of complement of the bactericidal activity of neutrophils in vitro. J. Clin. Invest. 52: 802-809.

28. Beauchamp, C., and I. Fridovich. 1970. A mechanism for the production of ethylene from methional. The generation of the hydroxyl radical by xanthine oxidase. J. Biol. Chem. 245: 4641-4646.

29. Cornu, A., and R. Massot. 1966. Compilation of Mass Spectral Data. Heyden \& Son Ltd, London. 1B.

30. McFadden, W. H. 1973. Techniques of Combined Gas Chromatography/Mass Spectrometry: Applications in Organic Analysis. John Wiley \& Sons, Inc., New York, 48.

31. Curnutte, J. T., D. M. Whitten, and B. M. Babior. 1974
Defective superoxide production by granulocytes from patients with chronic granulomatous disease. $N$. Engl. J. Med. 290: 593-597.

32. Root, R. K., J. Metcalf, N. Oshino, and B. Chance. 1975. $\mathrm{H}_{2} \mathrm{O}_{2}$ release from human granulocytes during phagocytosis. I. Documentation, quantitation, and some regulating factors. J. Clin. Invest. 52: 741-754.

33. Cheson, B. D., R. L. Christensen, R. Speiling, B. E. Kohler, and B. M. Babior. 1976. The origin of the chemiluminescence of phagocytosing granulocytes. J. Clin. Invest. 58: 789-796.

34. Anderson, B. R., and A. M. Brendzel. 1978. Use of a unique chemiluminescence spectrometer in a study of factors influencing granulocyte light emission. J. Immunol. Methods. 19: 279-287.

35. Sagone, A. L., D. S. Mendelson, and E. N. Metz. 1977. The effect of sodium azide on the chemiluminescence of granulocytes-evidence for the generation of multiple oxygen radicals. J. Lab. Clin. Med. 89: 1333-1340.

36. Dorfman, L. M., and G. E. Adams. 1973. Reactivity of the hydroxyl radical in aqueous solutions. U. S. Department of Commerce, National Bureau of Standards. NSRDS-NBS no 46. 1-59.

37. Neta, P., and L. M. Dorfman. 1968. Pulse radiolysis studies. XIII. Rate constants for the reaction of hydroxyl radical with aromatic compounds in aqueous solutions. Adv. Chem. Sci. 81: 222-230.

38. Cederbaum, A. I., E. Dicker, and G. Cohen. 1978. Effect of hydroxyl radical scavengers on microsomal oxidation of alcohols and on associated microsomal reactions. Biochemistry. 17: 3058-3064.

39. Stossel, T. P. 1973. Evaluation of opsonic and leukocyte function with a spectrophotometric test in patients with infection and with phagocytic disorders. Blood. 42: 121130.

40. Verhoef, J., P. K. Peterson, and P. G. Quie. 1977. Kinetics of staphylococcal opsonization, attachment, ingestion, and killing by human polymorphonuclear leukocytes: a quantitative assay using ${ }^{3} \mathrm{H}$-thymidine labeled bacteria. J. Immunol. Methods. 14: 303-311.

41. McCord, J. M., and I. Fridovich. 1968. The reduction of cytochrome c by milk xanthine oxidase. J. Biol. Chem. 243: 5753-60.

42. Walling, C. 1975. Fenton's reagent revisited. Accounts Chem. Res. 8: 125-131.

43. Cohen, G. 1978. The generation of hydroxyl radicals in biologic systems: toxicological aspects. Photochem. Photobiol. 28: 669-675.

44. Fridovich, I. 1978. The biology of oxygen radicals. Science (Wash. D. C.). 201: 875-880.

45. Gilbert, B. C., R. O. C. Norman, and R. C. Sealy. 1975. Electron spin resonance studies. Part XLIII. Reaction of dimethyl sulphoxide with hydroxyl radical. J. Chem. Soc. Perkin Trans. II. 303-308.

46. Lagercrantz, C., and S. Forshult. 1969. Trapping of shortlived free radicals as nitroxide radicals detectable by ESR spectroscopy. The radicals formed in the reaction between $\mathrm{OH}$ radicals and some sulphoxides and sulphones. Acta. Chem. Scand. 23: 811-817.

47. Carton, P. M., B. C. Gilbert, H. A. H. Lane, R. O. C. Norman, and R. C. Sealy. 1975. Electron spin resonance studies. Part XLVII. Sulphenyl- and sulphonyl-substituted aliphatic radicals. J. Chem. Soc. Perkin Trans. II. 12451249.

48. Rosen, H., and S. J. Klebanoff. 1979. Bactericidal activity of a superoxide anion-generating system. A model for the polymorphonuclear leukocyte. J. Exp. Med. 149: 27-39. 
49. Gregory, E. M., and I. Fridovich. 1974. Oxygen metabolism in Lactobacillus plantarum. J. Bacteriol. 117: 166-169.

50. Klebanoff, S. J. 1974. Role of the superoxide anion in the myeloperoxidase mediated antimicrobial system. J. Biol. Chem. 249: 3724-3728.

51. Rosenbaum, E. E., and S. W. Jacob. 1964. Dimethyl sulfoxide (DMSO) in musculoskeletal injuries and inflammations. II. Dimethyl sulfoxide in rheumatoid arthritis, degenerative arthritis. Northwest Med. 63: 227-229.

52. Wood, D. C., and J. Wood. 1975. Pharmacologic and biochemical considerations of dimethyl-sulfoxide. Ann. N.Y. Acad. Sci. 243: 7-19.

53. Shirley, S. W., B. H. Stewart, and S. Mirelman. 1978. Dimethyl sulfoxide in treatment of inflammatory genitourinary disorders. Urology. XI: 215-220.

54. French, J. E., W. J. Flor, M. P. Grissom, J. L. Parker, G. Sajko, and W. G. Ewald. 1977. Recovery, structure, and function of dog granulocytes after freeze-preservation with dimethylsulfoxide. Cryobiology. 14: 1-14.

55. Spector, J. I., J. A. Yarmala, L. D. Marchionni, C. P. Emerson, and C. R. Valeri. 1977. Viability and function of platelets frozen at 2 to $3 \mathrm{C}$ per minute with 4 or 5 per cent DMSO and stored at $-80 \mathrm{C}$ for 8 months. Transfusion (Phila.). 17: 8-15.

56. Farrant, J., and A. E. Woolgar. 1972. Human red cells under hypertonic conditions; a model system for investigating freezing damage. 3. dimethylsulfoxide. Cryobiology. 9: $131-136$.

57. Mironescu, S. 1978. Hyperosmotic injury in mammalian cells. 3. volume and alkali cation alteration of $\mathrm{CHO}$ cells in unprotected and DMSO-treated cultures. Cryobiology. 15: 178-191.

58. Rubin, L. F. 1975. Toxicity of dimethyl sulfoxide alone and in combination. Ann. N. Y. Acad. Sci. 243: 98-103.

59. Pribor, D. B. 1975. Biological interactions between cell membranes and glycerol or DMSO. Cryobiology. 12: 309320.

60. Leake, C. D. 1966. Dimethyl sulfoxide. Science (Wash. D. C.). 152: 1646-1649.

61. Jacob, S. W., M. Bischel, and R. J. Herschler. 1964. Dimethyl sulfoxide (DMSO): a new concept in pharmacotherapy. Curr. Ther. Res. Clin. Exp. 6: 134-148. 